\title{
Disease control during peach preservation with a berberine-chitosan composite membrane
}

\author{
Chunqi YaN ${ }^{1}$, Xizhen $\mathrm{GE}^{2}$, Pingfang TIAN ${ }^{1 *}$
}

${ }^{1}$ Coll. Life Sci. Technol., Beijing Univ. Chem. Technol., Beijing, China 100029, tianpf@mail.buct.edu.cn

${ }^{2}$ Biochem. Eng. Coll., Beijing Union Univ., Beijing, China 100023

${ }^{*}$ Correspondence and reprints

Fruits, 2012, vol. 67, p. 277-284 (C) 2012 Cirad/EDP Sciences All rights reserved DOI: 10.1051/fruits/2012020 www.fruits-journal.org

RESUMEN EsPañol, p. 284

\section{Disease control during peach preservation with a berberine-chitosan composite membrane.}

Abstract - Introduction. Peach brown rot caused by the fungus Monilinia fructicola is a major disease leading to considerable economic loss during storage. Our previous study uncovered the striking inhibition of the natural alkaloid berberine against $M$. fructicola. Materials and methods. A berberine-chitosan composite membrane (BCCM) able to slowly release berberine was prepared and used for peach preservation. The examined fruits were stored at $4{ }^{\circ} \mathrm{C}$ and treated as follows: (I) control fruits without packaging; (ii) fruits that were transiently immersed in pre-solidified BCCM liquid and taken out; (iii) fruit coating either with a BCCM, or with a membrane containing chitosan only (without berberine), and (iv) fruit coating with a PVC membrane. Results and discussion. The group immersed in BCCM showed a high infection rate due to the cytotoxicity of acetic acid, but the coating group showed only a $10 \%$ infection rate after 40 days of storage. Moreover, the BCCM-coating group showed a significantly lower infection rate than that coated with chitosan membrane (without berberine), clearly indicating the antimicrobial activity of berberine therein. Consequently, packed in BCCM and stored at $4{ }^{\circ} \mathrm{C}$, peach fruits could be well preserved over 40 days with very low infection. Conclusion. Considering its safety and low cost, the berberine-containing chitosan composite membrane could be applicable in controlling diseases during peach storage.

China / Prunus persica / peaches / storage / disease control / Monilinia fructicola / postharvest technology / coating / membranes

\section{Protection sanitaire de la pêche en cours de stockage à l'aide d'une membrane composite de berbérine-chitosane.}

Résumé - Introduction. La pourriture brune de la pêche causée par le champignon Monilinia fructicola est une maladie grave entraînant une perte économique considérable pendant le stockage. L'une de nos études précédentes avait mis en évidence l'inhibition surprenante de la berbérine, alcaloïde naturel, contre M. fructicola. Matériel et méthodes. Une membrane composite de berbérine-chitosane (BCCM) capable de libérer lentement de la berbérine a été préparée et utilisée pour la protection de pêches. Les fruits étudiés ont été stockés à $4{ }^{\circ} \mathrm{C}$ et ont subi les traitements suivant: (i) fruits témoins sans emballage; (ii) fruits transitoirement immergés dans une solution de BCCM pré-solidifiée, puis sortis; (iii) fruits revêtus soit avec une membrane BCCM, soit avec une membrane à base de chitosane seule (sans berbérine), et (iv) fruits revêtus avec un film de PVC. Résultats et discussion. Les fruits immergés dans une solution de BCCM ont montré un taux d'infection élevé du fait de la cytotoxicité de l'acide acétique présent dans le liquide, mais les fruits avec revêtement n'ont présenté que $10 \%$ de fruits infectés après 40 jours de stockage. De plus, les fruits revêtus d'une membrane BCCM ont présenté un taux d'infection significativement plus faible que celui des fruits revêtus d'une membrane de chitosane (sans berbérine) ; la berbérine aurait donc une activité antimicrobienne. En conséquence, les pêches emballées dans une membrane BCCM et stockées à $4{ }^{\circ} \mathrm{C}$ pourraient être conservées plus de 40 jours dans de bonnes conditions avec un taux d'infection très faible. Conclusion. Compte tenu de son efficacité et de son faible prix, la membrane composite de berbérine-chitosane pourrait être utilisable pour contrôler les maladies de stockage de la pêche.

Chine / Prunus persica / pêche (fruits) / stockage / contrôle de maladies / Monilinia fructicola / technologie après récolte / enrobage / membrane 


\section{Introduction}

Peach (Prunus persica L.) is a favorite fruit widely planted in the world. Since its harvest period is around summer and fall with scorching temperatures, the fruits are prone to be infested by fungi or bacteria and thus decay rapidly. Among the factors affecting storage, brown rot caused by the ascomycete fungus Monilinia fructicola (Wint) Honey is the main disease. Over the past decades, a myriad of chemical fungicides have been employed to control this disease [1, 2]. Unfortunately, M. fructicola has developed fungicide resistance due to frequent application [1-5]. Evidently, the conventional chemical fungicides have become ineffective for the control of $M$. fructicola. They have also resulted in environmental pollution, fruit contamination, and pose a threat to humans. For these reasons, it is imperative to seek substitutes from naturally occurring compounds.

In recent years, natural fungicides from medicinal plants have been greatly investigated $[6,7]$. Our previous study reported the notable inhibition of berberine against M. fructicola [8]. This finding aroused an interest in utilizing berberine to manage brown rot. In addition to berberine, chitosan, a well-studied natural polymeric material, has versatile properties such as bacteriostasis [9-11], film-forming ability, and safety to the environment. These traits have been confirmed by the practices of plant protection and preservation of fruits and vegetables [12, 13].

In the present study, to integrate the advantages of berberine and chitosan, a berberine-chitosan composite membrane (hereafter BCCM) was prepared and utilized for controlling diseases during peach storage. Immersion and coating treatments were performed to investigate the storage performance at $4{ }^{\circ} \mathrm{C}$, involving the weight loss rate and infection rate. The prepared BCCM exhibited robust antimicrobial activity and impressive preservation efficacy. Since chitosan and berberine are biodegradable and edible, the BCCM will not bring a new wave of "white pollution" and is benign to mankind. Therefore, it is promising in management of peach storage diseases.

\section{Materials and methods}

\subsection{Reagents and instruments}

Chitosan of $85 \%$ deacetylation degree was purchased from Golden Shell Biochemical Co., Ltd. (China). Berberine was purchased from the China National Institute for the Control of Pharmaceutical and Biological Products. All other reagents were of analytical grade. The constant temperature oscillator and ultraviolet-visible spectrophotometer are products of Varian Inc., USA.

\subsection{Preparation of the composite membrane}

Based on previous experiments, twenty $\mathrm{g}$ of chitosan powder were added to $1000 \mathrm{~mL}$ of $2 \%$ acetic acid solution; when completely dissolved, glycerol and berberine were added at respective concentrations of $10 \%$ $(\mathrm{mL} / \mathrm{mL})$ and $234.38 \mu \mathrm{g} \cdot \mathrm{mL}^{-1}$. The mixture was constantly stirred at room temperature until the chitosan and berberine completely dissolved and finally became a solution of high viscosity, then incubated to completely remove the air bubbles. After pouring it onto a flat plank, and air-drying it for $30 \mathrm{~h}$ at room temperature, the membrane was gently peeled off (designated BCCM). The membrane without berberine was named the chitosan membrane (CM).

\subsection{Assay of berberine release from the BCCM}

To determine the dissolution rate of berberine from the BCCM, phosphate buffer of $\mathrm{pH} 6.8$ was chosen as a transmitter. Small shreds of BCCM were sealed in a dialysis pouch and plunged into the phosphate buffer. BCCM shreds were rotated in a constant temperature-type oscillator at $100 \mathrm{rpm}$ per min and $27^{\circ} \mathrm{C}$, sampled at the setting time, for each time added the tales doses fresh buffer. Berberine absorbance was determined by measuring the ultraviolet absorption of the solution at $345 \mathrm{~nm}$, which was exchanged for the concentration value. The cumulative release percentage of 
berberine was calculated according to the formula: Release rate $(\%)=C \times[V / M] \times S$. In this formula, " $C$ " is the concentration of berberine in solution at each release time $\left(\mu \mathrm{g} \cdot \mathrm{mL}^{-1}\right)$; " $V$ " is the volume of the extraction medium ( $\mathrm{mL}$ ); " $M$ " indicates the weight of the BCCM (mg); " $S$ " indicates the drug loading [14].

\subsection{Investigation of antifungal activity of the BCCM}

Collected from a commercial orchard in the Pinggu District of Beijing (China), M. fructicola was cultured in potato dextrose agar (PDA) media and the spores were harvested by flooding the growing colony with sterile water. The mycelium was eliminated by filtration. The spore suspension at a concentration of $5 \times 10^{4}$ spores $\mathrm{mL}^{-1}$ was evenly scattered over the PDA plate, and one small piece of BCCM/CM was placed onto the center. A PDA plate lacking a small piece of $\mathrm{BCCM} / \mathrm{CM}$ was considered as the control. The PDA plates were cultured at $27^{\circ} \mathrm{C}$ for subsequent observation. All operations were carried out in triplicate and under sterilized conditions.

\subsection{Peach storage at $4{ }^{\circ} \mathrm{C}$}

Okubao peach is a major cultivar in the Pinggu district, Beijing. Disease-free fruits of approximately equal weight were washed with tap water and dried in air. Three groups of fruits were, respectively, encapsulated with conventional PVC film, CM and BCCM. Fruits without packaging were used as the control. All fruits were wounded (3-mm diameter, 4-mm deep) with a sterile needle. Spore suspension $\left(15 \mathrm{~mL}, 5 \times 10^{4}\right.$ spores/ $\mathrm{mL}$ ) of M. fructicola was sprayed over the stabbed surface of fruits and stored at $4{ }^{\circ} \mathrm{C}$ for investigation.

\subsection{Statistical analysis}

Each treatment was carried out in triplicate $(50 \times 3,150$ in total). All data were treated with SPSS 10.0 statistical software; data are presented as mean \pm standard error of mean (SEM). Statistical analysis was performed by

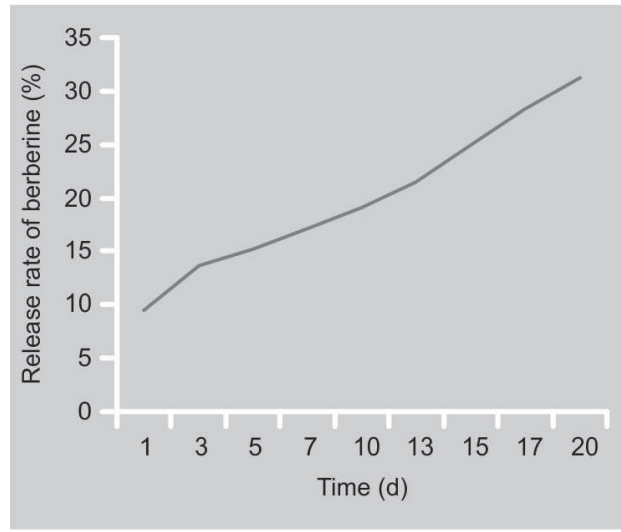

Figure 1.

In vitro release curve of berberine from the berberinechitosan composite membrane (BCCM) over 20 days. analysis of the $t$-test. $P$-values less than 0.05 were considered to be significant.

\section{Results}

\subsection{Berberine release from the BCCM}

The prepared membrane was flexible and manifested eligible mechanical properties involving tensile strength and elongation rate (data not shown). The berberine release rate reached $10 \%$ during the first day. In the following days, it slowed down and attained a 30\% cumulative release rate at the twentieth day (figure 1). Given the slow release of berberine, the BCCM could, for more than 1 month, inhibit pathogens surrounding the fruits, including brown rot fungus $M$. fructicola and a variety of Gram-positive and Gram-negative bacteria.

\subsection{Inhibition of the $\mathrm{BCCM}$ against M. fructicola}

With the experiments performed for investigating the antifungal activity of the BCCM, the inhibition of the BCCM against M. fructicola could be clearly observed after 5 days of culture (figure 2). Because the BCCM released berberine into the PDA medium, M. fructicola failed to grow around the BCCM. By contrast, M. fructicola grew well in the CM-covered PDA plate due to absence of berberine. 


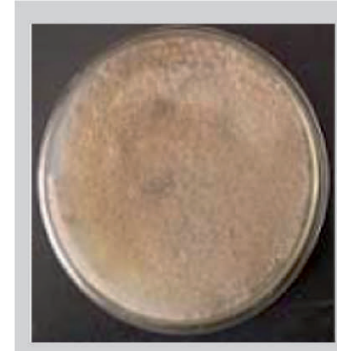

Control

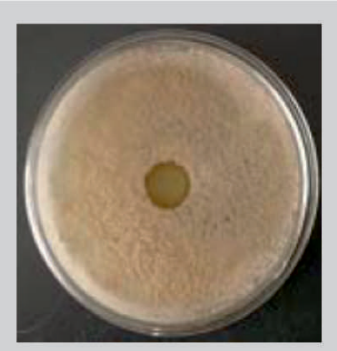

Chitosan membrane containing: $2 \%$ chitosan, $2 \%$ acetic acid $10 \%$ glycerol

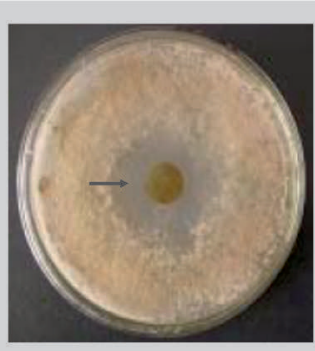

BCCM membrane containing: $2 \%$ chitosan, $2 \%$ acetic acid $10 \%$ glycerol, $234.38 \mu \mathrm{g}$ berberine $\cdot \mathrm{mL}^{-}$
Figure 2.

In vitro inhibition of the berberine-chitosan composite membrane (BCCM) against Monilinia fructicola according to three treatments: control without membrane; and medium covered with a piece of either a chitosan membrane or a BCCM membrane. Arrowhead indicates the berberine leakage area.

Figure 3.

Daily weight loss rate of peaches with different packaging and stored at $4{ }^{\circ} \mathrm{C}$ (CM: chitosan membrane; BCCN: berberine-chitosan composite membrane; PVC: polyvinyl chloride film).

\subsection{Weight loss rate of peach during storage}

The immersion treatment showed visible chemical damage to fruits due to acetic acid in the BCCM and CM. To overcome this drawback, coating treatments were performed. The weight loss rates varied among coating treatments (figure 3). The waterretention efficacy of the BCCM was better

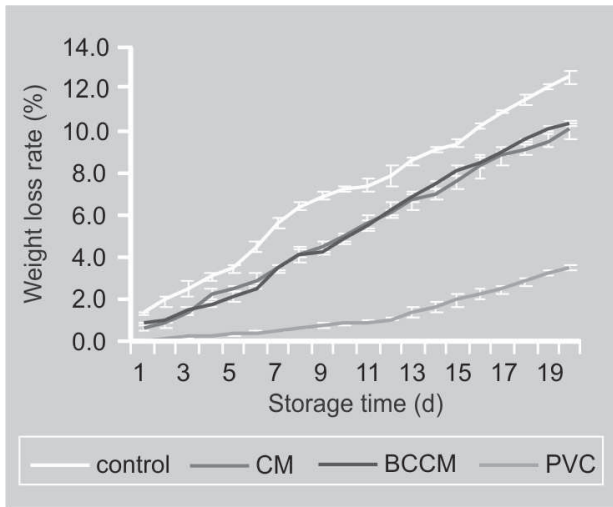

than the efficacy of the control group $(P<0.05$, table $I)$, but it was inferior to that of the PVC group, because of the tight chemical structure. No obvious difference was observed between the CM and BCCM in water retention. The daily weight loss rate of the coating treatment as a whole was obviously lower than the immersion treatment, because the free acetic acid in the BCCM solution (immersion treatment) eroded the fruits and therefore facilitated the invasion of microbes and led to decay. As a consequence, its weight loss rate was high.

\subsection{Infection incidence of peach during storage}

Infection incidence in the PVC group was higher than that in the control (figure 4, table I), mainly because of the high humidity caused by the tight PVC film, which facilitated the infection and propagation of fungi and bacteria. Notably, the infection incidence of the BCCM treatment was lower than that of the CM $(P<0.05)$, clearly indicating the antimicrobial activity of berberine therein (figure 4). Besides, the daily infection incidence in the coating group was significantly lower than that of the immersion group (BCCM vs. BCCM solution: $P<0.05$, figure 5). No chemical damage (cytotoxicity) on the fruit surface is visible to the naked eye in the coating group (figure $)$ ). This result can be explained by the following reasons: (i) the BCCM is a solid film and thus alleviates the close adherence of acetic acid to fruits, and (ii) the BCCM prevents bacteria and fungi from infecting fruits. In fact, at $4{ }^{\circ} \mathrm{C}$ the fruits could be well preserved; no
Table I.

Performance of peaches after 40 days of storage at $4{ }^{\circ} \mathrm{C}$ when coated with different packaging (CM: chitosan membrane; $\mathrm{BCCN}$ : berberine-chitosan composite membrane; PVC: polyvinyl chloride film).

\begin{tabular}{lcccc}
\hline Storage performance & Control & CM & BCCM & PVC \\
Weight loss rate & - & $P<0.05$ & $P<0.05$ & $P<0.01$ \\
Infection incidence & - & $P<0.05$ & $P<0.01$ & $P<0.05^{*}$ \\
\hline $\begin{array}{l}\text { All results are in comparison with the control. } \\
\text { * Higher infection incidence than the control. }\end{array}$ & & & \\
\end{tabular}


shrinkage or collapsed fruits were observed after 40 days of storage. Overall, the BCCM was verified to be a promising packaging material for peach preservation.

\section{Discussion}

As a major postharvest disease, brown rot considerably reduces peach yield. Although chemical fungicides are popular in production via spraying or fumigation [15, 16], they have encountered obstacles in application. In recent years, due to withdrawal of conventional chemical fungicides from the market, vast efforts have been shifted to biocontrol, fungicide mixture [17-19] or naturally occurring fungicides, especially those derived from medicinal plants [6, 7]. Here, both berberine and chitosan belong to natural compounds. On one hand, as lead compounds, they are likely developed into novel fungicides (unnatural compounds) by structural modification. On the other hand, due to bio-affinity, their combination may present outperforming antimicrobial activity. This "cocktail" strategy is in accordance with Chinese traditional medicines, which tune diseases using myriads of ingredients, including the leading and the auxiliary [20].

Two major conclusions can be drawn from our study. (i) The BCCM can slowly release berberine under a simulated environment (pH 6.8 phosphate buffer). Although the actual storage conditions may be different from the simulated ones, berberine can escape from the BCCM due to high humidity caused by fruit respiration. The antimicrobial activity of the BCCM far exceeds the CM (without berberine), clearly indicating the inhibition of berberine against pathogens around the fruits. (ii) Packed with

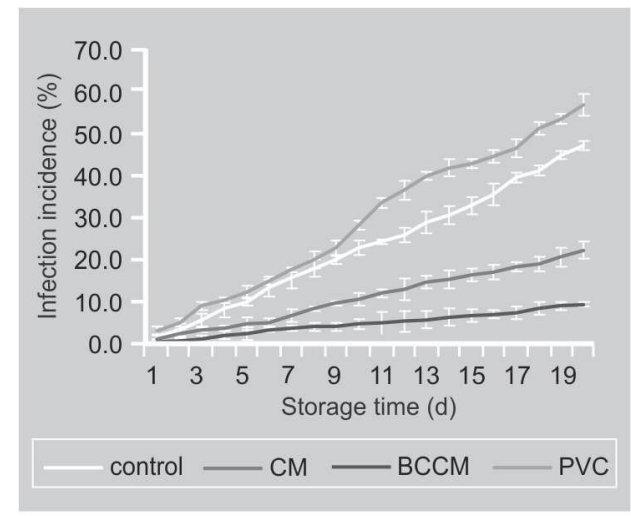

Figure 4

Infection incidence of peaches with different packaging and stored at $4{ }^{\circ} \mathrm{C}$ (CM: chitosan membrane; BCCN: berberinechitosan composite membrane; PVC: polyvinyl chloride film).

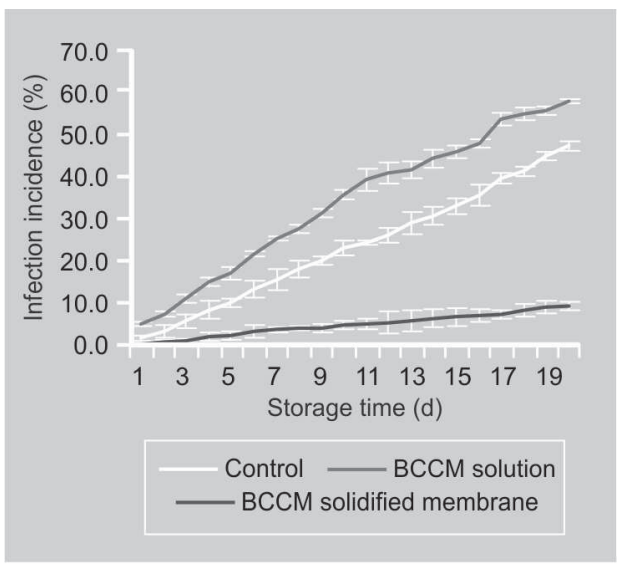

Figure 5.

Comparison of infection incidence of peaches between berberine-chitosan composite membrane (BCCM) coating and immersion treatments in BCCM solution (pre-solidified solution).
BCCM, fruits could be well preserved for more than 20 days at $25^{\circ} \mathrm{C}$ or 40 days at $4^{\circ} \mathrm{C}$. The novelty of this study was the integration of chitosan and berberine. To our knowledge, this is the first report of combining berberine with chitosan to control peach brown rot.

The antimicrobial activity of the BCCM can be explained by the following reasons: first, plentiful studies have validated the broad antibacterial spectrum of berberine, not only inhibiting Gram-positive bacteria

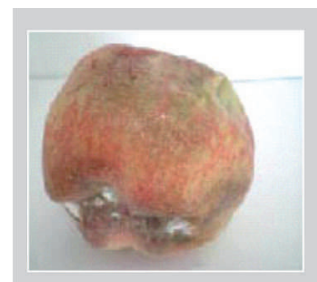

Control

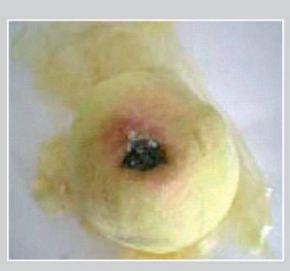

Coated with chitosane membrane

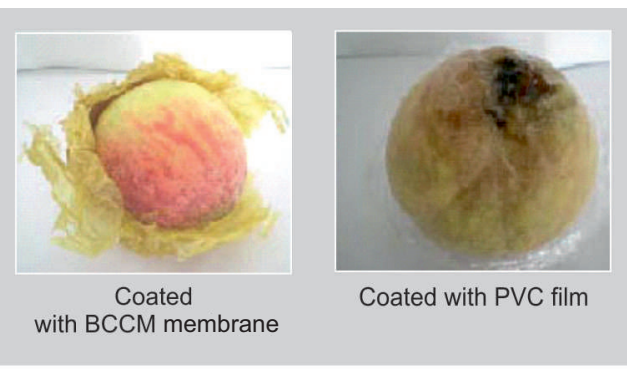

Figure 6.

40 days of storage performance of fruits with different packaging (control: no coating; $\mathrm{CM}$ : coating with chitosan membrane; BCCN: coating with berberinechitosan composite membrane; PVC: coating with polyvinyl chloride film). 
[21], but Gram-negative bacteria as well [22]. Second, berberine retards the growth of some fungi [23]. For example, our previous study reported the strong inhibition of berberine against $M$. fructicola [8]. Furthermore, chitosan was reported to inhibit bacteria [24]. Since the combination of berberine with chitosan may inhibit a wide range of microbes, the microbial quantity on the fruit surface could be considerably reduced upon BCCM treatment.

As an edible compound, chitosan is the sole natural basic polysaccharide uncovered so far. It has attracted great interest for its properties, including biodegradability, bioaffinity, low toxicity, film-forming capacity [11, 25] and ascendant permeability [26]. Besides, chitosan can induce plants to generate a defense response [27]. To our regret, when preparing the BCCM, chitosan was dissolved by acetic acid, which unexpectedly damaged the fruit. Hence, with the ingredients present here, BCCM immersion is not suitable for peach preservation. Nevertheless, we can envision the ultimate goal: the closely adherent BCCM will inhibit most of the microorganisms surrounding the fruit, but with no cytotoxicity. Towards this goal, in-depth study is required, including the selection of appropriate membrane ingredients and optimization of the processing method.

Regarding the berberine residue on fruits, it is likely to be monitored, but there is a threshold limit below which the content is not dangerous for consumers. Berberine residue at a low dose is safe, because berberine is a traditional antidiarrheal medicine used by Asians for centuries. Compared with the immersion treatment, the BCCMcoating treatment demonstrated advantages. Upon further optimization, the berberine-containing composite membrane could be applicable in the control of diseases during peach preservation.

\section{Acknowledgements}

The work was supported by the Beijing Golden Bridge Program managed by the
Beijing Association for Science and Technology of China.

\section{References}

[1] Holb I.J., Schnabel G., Differential effect of triazoles on mycelial growth and disease measurements of Monilinia fructicola isolates with reduced sensitivity to DMI fungicides, Crop Prot. 26 (2007) 753-759.

[2] Luo C.X., Schnabel G., The cytochrome P450 lanosterol 14 -demethylase gene is a demethylation inhibitor fungicide resistance determinant in Monilinia fructicola field isolates from Georgia, Appl. Environ. Microbiol. 74 (2008) 359-366.

[3] Ma Z.H., Yoshimura M.A., Michailides T.J., Identification and characterization of benzimidazole resistance in Monilinia fructicola from stone fruit orchards in California, Appl. Environ. Microbiol. 69 (2003) 7145-7152.

[4] Luo Y., Ma Z.H., Michailides T.J., Quantification of allele E198A in beta-tubulin conferring benzimidazole resistance in Monilinia fructicola using real-time PCR, Pest Manag. Sci. 63 (2007) 1178-1184.

[5] Holb I.J., Schnabel G., The benefits of combining elemental sulfur with a DMl fungicide to control Monilinia fructicola isolates resistant to propiconazole, Pest Manag. Sci. 64 (2008) 156-64.

[6] Ponce A.G., Roura S.I., del Valle C.E., Moreira M.R., Antimicrobial and antioxidant activities of edible coatings enriched with natural plant extracts: in vitro and in vivo studies, Postharvest Biol. Technol. 49 (2008) 294-300.

[7] Feng X.Y., Wang B.G., Li W.S., Shi L., Cao J.K., Jiang W.B., Preharvest application of phellodendron bark extracts controls brown rot and maintains quality of peento-shaped peach, HortScience 43 (2008) 1857-1863.

[8] Hou D.Y., Yan C.Q., Liu H.X., Ge X.Z., Xu W.J., Tian P.F., Berberine as a natural compound inhibits the development of brown rot fungus Monilinia fructicola, Crop Prot. 29 (2010) 979-984.

[9] Helander I.M., Nurmiaho-Lassila E.L., Ahvenainen R., Rhoades J., Roller S., Chitosan disrupts the barrier properties of the outer membrane of Gram-negative bacteria, Int. J. Food Microbiol. 71 (2001) 235-244. 
[10] Takahashi T., Imai M., Suzuki I., Sawai J., Growth inhibitory effect on bacteria of chitosan membranes regulated with deacetylation degree, Biochem. Eng. J. 40 (2008) 485491.

[11] Hosseini M.H., Razavi S.H., Mousavi M.A., Antimicrobial, physical and mechanical properties of chitosan-based films incorporated with thyme, clove and cinnamon essential oils, J. Food Process. Preserv. 33 (2009) 727-743.

[12] Campaniello D., Bevilacqua A., Sinigaglia M., Corbo M.R., Chitosan: antimicrobial activity and potential applications for preserving minimally processed strawberries, Food Microbiol. 25 (2008) 992-1000.

[13] Sangsuwan J., Rattanapanone N., Rachtanapun P., Effect of chitosan/methyl cellulose films on microbial and quality characteristics of fresh-cut cantaloupe and pineapple, Postharvest Biol. Technol. 49 (2008) 403-410.

[14] Yu C.Y., Zhang X.C., Zhou F.Z., Zhang X.Z., Cheng S.X., Zhuo R.X., Sustained release of antineoplastic drugs from chitosan-reinforced alginate microparticle drug delivery systems, Int. J. Pharm. 357 (2008) 15-21.

[15] Liu W.T., Chu C.L., Zhou T., Thymol and acetic acid vapors reduce postharvest brown rot of apricots and plums, HortScience 37 (2002) 151-156.

[16] Svircev A.M., Smith R.J., Zhou T., Hernadez M., Liu WT, Chu C.L., Effects of thymol fumigation on survival and ultrastructure of Monilinia fructicola, Postharvest Biol. Technol. 45 (2007) 228-233.

[17] Emery K.M., Scherm H., Savelle A.T., Assessment of interactions between components of fungicide mixtures against Monilinia fructicola, Crop Prot. 21 (2002) 41-47.

[18] Guijarro B., Melgarejo P., Torres R., Lamarca N., Usall J., De Cal A., Effects of different biological formulations of Penicillium frequentans on brown rot of peaches, Biol. Control 42 (2007) 86-96.
[19] Zhou T., Schneider K.E., Li X.Z., Development of biocontrol agents from food microbial isolates for controlling post-harvest peach brown rot caused by Monilinia fructicola, Int. J. Food Microbiol. 126 (2008) 180185.

[20] Wang L., Zhou G.B., Liu P., Song J.H., Liang Y., Yan X.J., Xu F., Wang B.S., Mao J.H., Shen Z.X., Chen S.J., Chen Z., Dissection of mechanisms of Chinese medicinal formula Realgar-Indigo naturalis as an effective treatment for promyelocytic leukemia, Proc. Natl. Acad. Sci. U.S.A. 105 (2008) 4826-4831.

[21] Iwasa K., Nanba H., Lee D.U., Kang S.I., Structure-activity relationships of protoberberines having antimicrobial activity, Planta Med. 64 (1998) 748-51.

[22] Stermitz F.R., Lorenz P., Tawara J.N., Zenewicz L.A., Lewis K., Synergy in a medicinal plant: antimicrobial action of berberine potentiated by 5 '-methoxyhydnocarpin, a multidrug pump inhibitor, Proc. Natl. Acad. Sci. U.S.A. 97 (2000) 1433-1437.

[23] Basha S.A., Mishra R.K., Jha R.N., Pandey V.B., Singh U.P., Effect of berberine and (+/-)bicuculline isolated from Corydalis chaerophylla on spore germination of some fungi, Folia Microbiologica 47 (2002) 161-165.

[24] Je J.Y., Kim, S.K., Chitosan derivatives killed bacteria by disrupting the outer and inner membrane, J. Agric. Food Chem. 54 (2006) 6629-6633.

[25] Sebastien F., Stephane G., Copinet A., Coma V., Novel biodegradable films made from chitosan and poly(lactic acid) with antifungal properties against mycotoxinogen strains, Carbohydr. Polym. 65 (2006) 185-193.

[26] Takahashi T., Imai T., Suzuki I., Water permeability of chitosan membrane involved in deacetylation degree control, Biochem. Eng. J. 36 (2007) 43-48.

[27] Doares S.H., Syrovets T., Weiler E.W., Ryan C.A., Oligogalacturonides and chitosan activate plant defensive genes through the octadecanoid pathway, Proc. Natl. Acad. Sci. U.S.A. 92 (1995) 4095-4098. 
Protección sanitaria del melocotón en curso de almacenamiento con ayuda de una membrana composite de berberina-chitosán.

Resumen - Introducción. La podredumbre morena del melocotón, causada por el hongo Monilinia fructicola es una enfermedad grave que acarrea una pérdida económica considerable durante el almacenamiento. Uno de nuestros anteriores estudios puso de manifiesto la sorprendente inhibición de la berberina, alcaloide natural, contra $M$. fructicola. Material y métodos. Se preparó una membrana composite de berberina-chitosán (BCCM) capaz de soltar lentamente berberina y se utilizó para proteger los melocotones. Se almacenaron los frutos estudiados a $4^{\circ} \mathrm{C}$ y se les sometió a los siguientes tratamientos: (i) frutos testigo sin envoltura; (ii) frutos transitoriamente sumergidos en una solución de BCCM presolidificada, y, a continuación, sacados; (iii) frutos revestidos o bien con una membrana BCCM o bien con una membrana a base de chitosán únicamente (sin berberina), y (iv) frutos revestidos con una película de PVC. Resultados y discusión. Los frutos sumergidos en una solución BCCM mostraron un índice de infección elevado, por el hecho de la citotoxicidad del ácido acético presente en el líquido, sin embargo, después de 40 días de almacenamiento, los frutos con revestimiento sólo presentaron un $10 \%$ de frutos infectados. Además, los frutos revestidos con una membrana BCCM presentaron un índice de infección significativamente más flojo que el de los frutos revestidos con una membrana de chitosán (sin berberina); por lo tanto, se supone que la berberina posee una actividad antimicrobiana. En consecuencia, los melocotones envueltos en una membrana BCCM y almacenados a $4{ }^{\circ} \mathrm{C}$ podrían conservarse más de 40 días en buenas condiciones con un índice de infección muy flojo. Conclusión. Habida cuenta de su eficacia y de su bajo precio, la membrana composite de berberina-chitosán podría utilizarse para controlar las enfermedades de almacenamiento del melocotón.

China / Prunus persica / durazno / almacenamiento / control de enfermedades / Monilinia fructicola / tecnología postcosecha / revestimiento / membrana 